\title{
Pendapat Syaikh Nizhamuddin al-Balkhi dalam Kitab Fatawa Al-Hindiyyah tentang Ittishal antara Ijab dan Kabul Akad Nikah
}

\author{
Asep Koswara \\ Institut Agama Islam Darussalam (IAID) Ciamis, Jawa Barat \\ Email: asep.koswara2017@gmail.com \\ Hasan Bisri \\ Universitas Islam Negeri (UIN) Sunan Gunung Djati Bandung \\ Ayi Ishak Sholih Muchtar \\ Institut Agama Islam Darussalam (IAID) Ciamis, Jawa Barat
}

\begin{abstract}
ABSTRAK
Pernikahan dianggap sah apabila telah memenuhi rukun dan syarat pernikahan. Diantara rukun perkawinan adalah adanya ijab dan kabul. Berdasarkan hukum asalnya, ulama sependapat ijab itu datangnya dari pihak pengantin wanita, sedangkan kabul dari pengantin pria. Akan tetapi dalam masalah ittishal antara ijab dan kabul akad nikah para ulama berbeda pendapat. Apabila tidak ittishal antara ijab dan kabul nikah, maka akad tetap dianggap sah selagi masih fokus dalam prosesi akad dan tidak dalam jangka waktu yang lama. Tujuan dari penelitian yaitu, 1) mengetahui dan menganalisis pendapat Syaikh Nizhamuddin Al-Balkhi tentang ittishal antara ijab dan kabul dalam akad nikah, 2) mengetahui dasar dalil hukum yang digunakan oleh Syaikh Nizhamuddin Al-Balkhi tentang ittishal antara ijab dan kabul dalam akad nikah, dan 3) mengetahui metode ijtihad yang digunakan dalam istimbath al-hukminya. Dalam penelitian skripsi ini penulis menggunakan metode penelitian kualitatif yaitu metode penelitian yang menghasilkan data deskriptif berupa kata-kata atau ucapan tertulis dari orang-orang atau perilaku yang diamati. Jenis penelitian ini adalah library research. Hasil penelitian menunjukkan, 1) Hukum ittishal antara ijab dan kabul nikah menurut Syaikh Nizhamuddin Al-Balkhi dalam kitab fatawa alhindiyyah bahwa ittishal antara ijab dan kabul nikah itu hanya fi majlisin wahidin. Ittishal akad nikah yang berlaku di Indonesia diatur dalam Kompilasi Hukum Islam (KHI) pada pasal 27: ijab dan kabul antara wali dan calon mempelai pria harus jelas beruntun dan tidak berselang. 2) Dasar hukum yang digunakan oleh Syaikh Nizhamuddin Al-Balkhi dalam masalah ittishal antara ijab dan kabul akad nikah, yaitu hadits Nabi yang diriwayatkan oleh Abu Dawud. 3) Metode ijtihad yang digunakan oleh Syaikh Nizhamuddin Al-Balkhi adalah qiyas. Syaikh Nizhamuddin al-Balkhi mengqiyaskan akad nikah yang yang satu majlis tetapi tidak faur dengan
\end{abstract}


akad nikah yang diwakilkan dan berbeda tempat dengan syarat tetap harus ada saksi.

\section{ABSTRACT}

Marriage is considered valid if it has fulfilled the terms and conditions of marriage. Among the pillars of marriage are the consent and kabul. Based on the law of origin, the ulama agreed that the consent came from the bride, while the Kabul came from the groom. However, in the matter of ittishal between the consent and the marriage contract, the scholars have different opinions. If there is no ittishal between the consent and the marriage ceremony, then the contract is still considered valid while it is still focused on the contract procession and not for a long time. The objectives of the research are, (1) knowing and analyzing the opinion of Shaykh Nizhamuddin Al-Balkhi about ittishal between consent and kabul in the marriage contract, (2) knowing the basis of the legal arguments used by Shaykh Nizhamuddin Al-Balkhi regarding ittishal between consent and kabul in the marriage contract, and (3) knowing the ijtihad method used in his istimbath al-hukminya. In this thesis research the writer uses qualitative research methods, namely research methods that produce descriptive data in the form of words or written utterances from people or observed behavior. This type of research is a research library. The results showed, 1) The law of ittishal between consent and the marriage of marriage according to Shaykh Nizhamuddin Al-Balkhi in the fatawa al-hindiyyah book that ittishal between ijab and kabul nikah is only fi majlisin wahidin. The ittishal of the marriage contract that is valid in Indonesia is regulated in the Islamic Law Compilation (KHI) in article 27: consent and kabul between the guardian and the prospective groom must be clear in sequence and not intermittent. 2) The legal basis used by Shaykh Nizhamuddin Al-Balkhi in the matter of ittishal between consent and kabul akad nikah, namely the hadith of the Prophet narrated by Abu Dawud. 3) The ijtihad method used by Shaykh Nizhamuddin Al-Balkhi is qiyas. Shaykh Nizhamuddin al-Balkhi confirmed that the marriage contract was one majlis but did not work with the marriage contract that was represented and in a different place with the condition that there must still be witnesses.

Keywords: Ittishal, Ijab Kabul and Akad Nikah

\section{PENDAHULUAN}

Pernikahan atau perkawinan merupakan ikatan kokoh yang mengikatkan hati, melembutkannya, mencampurkan nasab dan menumbuhkan hubungan masyarakat menjadi kemaslahatan sehingga manusia dapat menjaga hubungan antar individu dan golongan. Dengan 
demikian hubungan kemasyarakatan akan menjadi lebih luas. Sungguh Allah SWT. telah menjadikan hubungan kekeluargaan karena perkawinan menjadi dasar nasab.

Allah SWT. berfirman: "Dan dia (pula) yang menciptakan manusia dari air lalu dia jadikan manusia itu (punya) keturunan dan mushaharah dan adalah Tuhanmu Maha Kuasa" (Q.S. Al-Furqan 54:1).

Tujuan dari keinginan dan kepentingan ini dibentuk pernikahan. Oleh karena itu, Allah Yang Maha Bijaksana meliputinya dengan ikatanikatan, aturan-aturan, dan hukum-hukum yang terperinci sejak permulaan pemikiran peminang hingga kesempurnaannya. Kemudian meliputi juga dengan setiap tanggungan-tanggungan yang bersifat materi dan maknawi sejak pelaksanaannya sehingga berakhirnya pernikahan sebab kematian atau yang lainnya untuk menjaga hak-hak semua pihak. Perkawinan adalah sunnah kauniyyah yang apabila dilaksanakan akan mendapat pahala tetapi apabila tidak dilaksanakan tidak mendapatkan dosa tetapi dimakruhkan karena tidak mengikuti sunah Rasul SAW. Akad nikah berbeda dengan transaksi yang lain karena mempunyai pengaruh yang penting dan sakral (Azzam \& Hawwas, 2011:7).

Adapun perkawinan dapat dianggap sah apabila didalamnya telah memenuhi beberapa rukun dan syarat. Abi Yahya Zakaria Al-Anshari dalam kitab Fath Al-Wahhab menetapkan ada lima rukun nikah, yaitu: mempelai pria, mempelai wanita, wali nikah, dua orang saksi, dan ijab dan kabul (Zakaria, 1998:35).

Rukun yang pokok dalam perkawinan ialah ridlanya laki-laki dan perempuan dan persetujuan mereka untuk mengikat hidup berkeluarga. Karena perasaan ridla dan setuju bersifat kejiwaan yang tidak dapat dilihat dengan mata kepala, karena itu harus ada perlambang yang tegas untuk menunjukkan kemauan mengadakan ikatan bersuami istri. Perlambang itu diutarakan dengan kata-kata oleh kedua belah pihak yang mengadakan akad.

Pernyataan pertama menunjukkan kemauan untuk membentuk hubungan suami istri di sebut ijab, dan pernyataan kedua yang dinyatakan oleh pihak yang mengadakan aqad berikutnya untuk menyatakan rasa ridla dan setujunya disebut kabul. Dari sini kemudian para Ulama fikih menyatakan bahwa rukun perkawinan adalah ijab dan kabul.

Disebutkan dalam kitab Fiqhu al-Sunnah, 2004:23 karya Muhammad Sayyid Sabiq, dijelaskan:

ويشترط الشافعية الفور. قالو ا فإن فصل بين القبول والإيجاب بخطبة بأن قال الولي زوجتك وقال الزوج بسم الله والحمد لله والصلاة والسلام على رسول الله صلى الله عليه وسلم قبلت نكاحها ففيه وجهان:

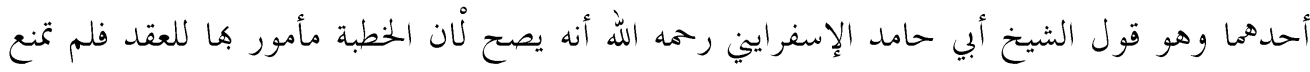




$$
\begin{aligned}
& \text { صحته كالتيمم بين صلاتي الجمع والثاني لًا يصح لْنه فصل بين الإيماب و القبول فلم يصح كما لو فصل }
\end{aligned}
$$

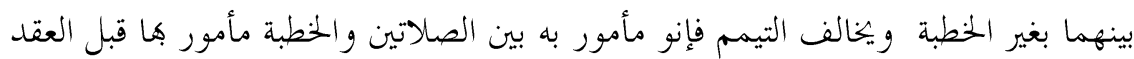

"Bahwasanya golongan Syafiyyah mensyaratkan harus faur antara ijab dan kabul, dalam hal ini terdapat perbedaan antara golongan Ulama Madzhab Syafi'i sendiri yang dipelopori oleh Imam Aljuwaini dan Syaikh Abu Ishaq Al-Syairazy yaitu apabila ijab qabul diselingi oleh khutbah, umpamanya: "Aku kawinkan kamu dengan si fulanah binti fulan". Lalu mempelai lakilaki menjawab: "bismillah walhamdulillah wa assholatu wa assalamu ala rasulillah shollallahu alaihi wa sallam aku terima nikahnya si fulanah binti fulan" dalam hal ini ada dua pendapat:

a. Syaikh Abu Hamid Al Isfirayini berpendapat sah. Karena khutbah dan aqad nikah diperintahkan Agama dan perbuatan ini tidak merupakan halangan sahnya akad nikah seperti halnya orang yang bertayammum antara dua sholat yang di jamak. Kedua: tidak sah, sebab memisahkan acara ijab dan kabul sebagaimana halnya kalau antara ijab kabul itu dipisahkan oleh hal-hal selain khutbah nikah. Dalam hal ini berbeda dengan hukum tayammum, karena tayammum di antara dua sholat yang di jamak adalah perintah Agama, sedangkan khutbah nikah diperintahkan sebelum ijab kabul".

b. Imam Syafi'i mengatakan bahwa khutbah antara ijab dan kabul tidak sah karena beralasan bahwa khuthbah tersebut memisahkan antara ijab dan kabul karena tidak ada hubungannya dengan akad sehingga dikhawatirkan jika hal tersebut bukan lagi satu majelis akad, yang mana para Ulama semua sepakat bahwa diantara syarat akad nikah yaitu satu majelis.

Dengan demikian, masalah pokok dalam penelitian ini, yaitu: Bagaimana pendapat Syaikh Nizhamuddin Al-Balkhi dalam kitab Fatawa Al-Hindiyyah tentang ittishal antara ijab dan kabul akad nikah?

\section{LANDASAN TEORI}

Konsep Akad

Secara etimologi akad berarti :

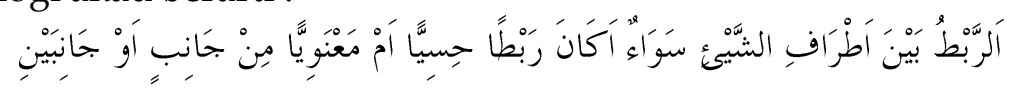

"Ikatan antara dua perkara,baik ikatan secara nyata maupun ikatan secara maknawi, dari satu segi maupun dua segi (Az-Zuhaili, 1989:80).

Bisa juga berarti العقدة (sambungan), dan العهد (janji).

Ulama hanafiyah berpendapat bahwa rukun akad adalah ijab dan kabul. Adapun orang yang mengadakan akad atau hal-hal lainnya yang menunjang terjadinya akad tidak dikatagorikan sebagai rukun sebab 
keberadaannya sudah pasti. Sedangkan ulama selain hanafiyah berpendapat bahwa akad memiliki tiga rukun, yaitu: (Syafei, 2006:45).
a. Orang yasg melakukan akad ('aqid)
b. Sesuatu yang diakadkan (ma'qud 'alaih)
c. Shighat, yaitu ijab dan kabul

\section{Shigat}

Ijab menurut ulama hanafiyah adalah penetapan perbuatan tertentu yang menunujukan keridlaan yang diucapkan oleh orang yang pertama baik yang menyerahkan maupun yang menerima, sedangkan kabul adalah orang yang berkata setelah orang yang mengucapkan ijab, yang menunjukan keridlaan atas ucapan orang pertama (syafei, 2006: 345).

Menurut pendapat Syaikh Nizhamuddin (2002:343), dalam kitab fatawa al-Hindiyyah menyebutkan bahwa nikah adalah akad yang mendatangkan dan mengakibatkan kepemilikan untuk bersenang-senang. Hukumnya secara umum adalah sunat muakaddan ketika sangat dibutuhkan dan takut terjadi zina maka menjadi wajib. Sedangkan rukun nikah diantaranya yaitu ijab dan kabul. Ijab yaitu lafadz awal yang digunakan dalam akad nikah dan kabul adalah jawaban daripada ijab.

Konsep Nikah

a. Menurut Bahasa

Menurut Syaikh Abi Yahya Zakariya (1998:35) Nikah menurut bahasa yaitu

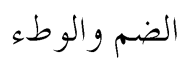

“Berkumpul dan wath'i.

Secara etimologi, kata kawin menurut bahasa sama dengan kata nikah, atau kata, zawaj. Kata nikah disebut dengan al nikh (النكاح) dan al ziwaj atau al zawj atau al zijah (الزواج-الزواج-الزيجه). Secara harfiah, kata al nikh berarti al wath'u (الوطء), adh-dhammu (الضم (الخمع)). Al wath'u al-jam'u berasal dari kata wathi'a - yatha'u - wath'an (وطأ-يطأ-وطأُ (و) artinya berjalan di atas, melalui, memijak, menginjak, memasuki, menaiki, menggauli dan bersetubuh atau bersenggama (al-Munawwir, 1997:1461).

Syaikh Kamil Muhammad 'Uwaidah mengungkapkan bahwa kata nikah menurut bahasa berarti penyatuan. Diartikan juga sebagai akad atau hubungan badan. Selain itu, ada juga yang mengartikannya dengan percampuran (Suma, 2004:42-43).

Para ulama memerinci makna lafal nikah ada empat macam: (Azzam \& Hawwas, 2011:38). 
a. Nikah diartikan akad dalam arti yang sebenarnya dan diartikan percampuran suami istri dalam arti kiasan.

b. Nikah diartikan percampuran suami istri dalam arti sebenarnya dan akad berarti kiasan.

c. Nikah lafal musytarak (mempunyai dua makna yang sama).

d. Nikah diartikan adh-dhammu (bergabung secara mutlak) dan al-ikhtilath (percampuran). Makna percampuran bagian dari adh-dhammu (bergabung) karena adh-dhammu meliputi gabungan fisik yang satu dengan yang lainnya dan gabungan ucapan yang satu dengan ucapan yang lain, yang pertama gabungan dalam bersenggama dan yang kedua gabungan dalam akad.

Kalangan para ulama sering mengatakan kata akad nikah, yang berasal dari dua kata, yaitu akad dan nikah. Akad sendiri artinya perjanjian, peryataan. Sedangkan nikah adalah perkawinan, perjodohan. Jadi akad nikah adalah peryataan sepakat (perjanjian) perkawinan (An-Nawawi, 2013:882).

Kalimat akad secara bahasa adalah menunjukkan arti perjanjian dan kesanggupan untuk bertanggung jawab. Tanggung jawab itu adalah fungsifungsi yang dituntut ketika kedua belah pihak menghendaki pernikahan, demi menegakkan hubungan keduanya secara syar'i. Sedangkan pernikahan menurut istilah adalah kesepakatan yang dimaksudkan untuk mendapat kehalalan antara masing-masing suami isteri dan keharmonisan demi mendapatkan keturunan dengan cara yang disyariatkan (Sabiq, 2004:194).

b. Menurut Istilah

Nikah menurut istilah yaitu:

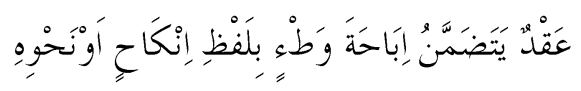

"Akad yang mengandung ketentuan hukum membolehkan hubungan intim dengan lafadz inkah atau yang serupa dengannya" (Zakariya, 1998:35).

Abdurrahman al-Jaziri (1990) mengemukakan bahwa golongan Syafi'iyah mendefinisikan akad nikah sebagai berikut:

$$
\text { عقد يتضمن ملك وطء بلفظ انكاح اوتزويج او معناهما }
$$

"Akad yang mengandung kekuasaan untuk watha (bersetubuh) dengan lafadz inkah atau tazwij atau yang semakna dengan keduanya" (al-Jaziri, 1990:8).

Sedangkan menurut golongan Hanafiyah sebagi berikut:

$$
\text { عقد يفيد ملك المتعة }
$$

"Akad yang memberi faidah untuk menguasai persetubuhan".

Sedangkan menurut golongan Malikiyah sebagai berikut:

$$
\text { عقدعلى بحردمتعة التلذذ بادمية غير موجب قيمتهابينة قبله }
$$


"Akad yang mengandung ketentuan hukum semata-mata untuk membolehkan wathi, bersenang-senang dan menikmati apa yang ada pada diri seorang wanita yang boleh dinikah dengannya."

Selanjutnya menurut golongan Hanabilah sebagai berikut:

$$
\text { عقد بلفظ انكاح اوتزويج على منفعة الاستمتاع }
$$

"Akad yang mempergunakan lafadz inkah atau tazwij untuk memperbolehkan manfaat, bersenang-senang dengan wanita" (al-Jaziri, 1990:9).

Menurut Abu Zahrah dalam bukunya al-Ahwal al-Syakhshiyyah bahwa pernikahan ialah Akad yang menghalalkan hubungan suami istri dari dua orang yang berakad sesuai dengan Syari'at Islam (Zahrah, 1950:17).

Menurut Kompilasi Hukum Islam (KHI) pasal 2, nikah adalah: "Akad yang sangat kuat atau miitsaaqan ghaliidhan untuk mentaati perintah Allah dan melaksanakannya merupakan ibadah" (Bisri, 1999:140).

Menurut UU No. 1 tahun 1974 tentang Perkawinan pasal 1: "Ikatan lahir batin antara seorang pria dengan seorang wanita sebagai suami istri dengan tujuan membentuk keluarga (rumah tangga) yang bahagia dan kekal berdasarkan Ketuhanan Yang Maha Esa".

Perkawinan adalah suatu perbuatan yang disuruh Allah SWT. dan juga disuruh oleh Nabi. Banyak suruhan Allah SWT. dalam al-Qur'an untuk melaksanakan perkawinan. Diantaranya Allah SWT. berfirman dalam surat An-Nur ayat 32: "Dan kawinkanlah orang-orang yang sedirian diantara kamu, dan orang-orang yang layak (berkawin) dari hamba-hamba sahayamu yang lelaki dan hamba-hamba sahayamu yang perempuan. jika mereka miskin Allah akan memampukan mereka dengan kurnia-Nya. dan Allah Maha Luas (pemberian-Nya) lagi Maha mengetahui" (Q.S. An-Nur 24:32). "Dan di antara tanda-tanda kekuasaan-Nya ialah Dia menciptakan untukmu isteri-isteri dari jenismu sendiri, supaya kamu cenderung dan merasa tenteram kepadanya, dan dijadikan-Nya diantaramu rasa kasih dan sayang. Sesungguhnya pada yang demikian itu benar-benar terdapat tandatanda bagi kaum yang berfikir".(Q.S. Ar-Ruum 30:21).

Ijab dan kabul yang diucapkan oleh pihak calon suami isteri itu dianggap sah apabila memenuhi syarat-syarat yang telah dijelaskan oleh syara'. Adapun syarat-syarat tersebut adalah: (al-Jaziri, 2009:9).

a) Ijab kabul harus dilakukan oleh calon suami isteri

b) Tidak sah hukumnya ijab kabul dilakukan karena terpaksa atau di paksa

c) Tidak sah dilakukan oleh orang gila.

d) Ijab kabul harus dilakukan dalam satu majelis yang sama dan dalam waktu yang sama. Imam Syafi'i mensyaratkan antara ijab dan kabul harus dilakukan denganbersambung, tidak boleh di sela dengan perkataan lain atau dengan terputus-putus. 
e) Dengan kata-kata tertentu dan tegas, yaitu diambil dari kata inkah atau tazwij atau terjemahannya.

Secara personal hukum nikah berbeda disebabkan perbedaan kondisi mukallaf, baik dari segi karakter kemanusiaannya maupun dari segi kemampuan hartanya. Menurut Abdul Aziz \& Abdul Wahab (2009) hukum nikah terbagi 5 bagian, yaitu:

a. Fardu

Hukum nikah fardu, pada kondisi seseorang yang mampu biaya wajib nikah, yakni biaya nafkah dan mahar dan adanya percaya diri bahwa ia mampu menegakan keadilan dalam pergaulan dengan istri yakni pergaulan dengan baik. Demikian juga dengan menikah pasti tidak akan melakukan zina, sedangkan puasa yang dianjurkan Nabi tidak akan mampu menghindarkan dari perbuatan tersebut. Nabi bersabda:

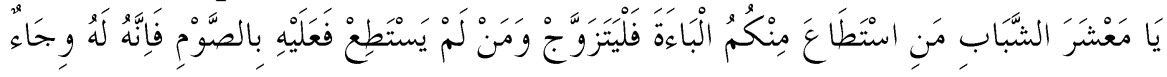

“Wahai para pemuda siapa saja di antara kamu yang telah sanggup untuk kawin, hendaklah ia kawin, karena dengan kawin mata akan legih terjaga dan kemaluan akan lebih terpelihara, dan bilamana kamu belum mampu untuk kawin, hendaklah kamu berpuasa, karena puasa itu ibaratkan pengembiri (benteng)" (al-Kahlani 1996:109).

Pada kondisi seperti diatas hukum nikah adalah fardu dan berdosa apabila tidak. Meninggalakn zina hukumnya fardu dan caranya yaitu menikah dengan tidak mengurangi hak seseorang makaia menjadi wajib. Menurut kaidah ushul figh:

$$
\text { ما لايتم الوجوب الا به فهو واجب }
$$

"Sesuatu yang tidak mencapai fardu kecuali dengan melakukannya, maka ia hukumnya fardu juga" (Zahrah, 2009:8).

b. Wajib

Hukum nikah menjadi wajib bagi seseorang yang memiliki kemampuan biaya nikah, mampu menegakan keadilan dalam pergaulan yang baik dengan pasangannya, dan mempunyai dugaaan kuat akan melakukan zina apabila tidak menikah.

c. Haram

Hukum nikah haram bagi seseorang yang tidak memiliki kemampuan nafkah dan yakni akan adanya penganiayaan jika menikah.

d. Makruh

Hukum nikah makruh bagi seseorang yang dalam kondisi campuran. Seseorang memiliki kemampuan harta biaya nikah dan tidak dikhawatirkan terjadi zina, tetapi dikhawatirkan adnya penganiayaan setelah menikah yang tidak sampai ke tingakat yakin.

e. Mubah

Hukum nikah mubah bagi seseorang yang tidak ada ragbah untuk menikah, tidak mengharapkan keturunan, tidak takut zina,dan tidak 
memutuskan terhadap ibadah wajib. Hukum nikah ini adalah hukum asalnya (Azzam \& Hawwas, 2009:43-47).

\section{METODE}

Metode penelitian atau yang biasa juga disebut prosedur penelitian ini dalam sebuah proposal penelitian skripsi memuat pelbagai aspek yang terkait dengan metodologi penelitian yang akan digunakan peneliti. Metodologi atau prosedur penelitian tersebut bisa berbeda antara satu penelitian dengan penelitian yang lain, tergantung kepada pendekatan,paradigma, masalah, dan tujuan penelitian yang akan dilakukan. (Thoyyar, 2015:7).

Metode penelitian ini menggunakan metode deskriptif analitif. Penelitian kualitatif menggunakan metode kualitatif yaitu pengamatan, wawancara, atau penelaahan dokumen. Metodekualitatif ini menggunakan pertimbangan. Pertama, menyesuaikan metode kualitatif lebih mudah apabila berhadapan dengan kenyataan jamak. Kedua, metode ini menyajikan secara langsung hakikat hubungan antara peneliti dan responden. Ketiga, metode ini lebih peka dan lebih dapat menyesuaikan diri dengan banyak penajaman pengaruh bersama terhadap pola-pola nilai yang dihadapi (Moleong, 2007:10).

Data merupakan sumber yang paling penting untuk menyingkap suatu permasalahan yang ada, dan data jugalah yang diperlukan untuk menjawab masalah penelitian atau mengisi hipotesis yang sudah dirumuskan. Dalam melakukan penelitian ini data-data yang diperlukan dari dua sumber yaitu :

Data primer adalah data yang bersumber dari informan yang mengetahui secara jelas dan rinci mengenai masalah yang diteliti. Sedangkan informan adalah orang yang dimanfaatkan untuk memberikan informasi tentang situasi dan kondisi yang dijadikan obyek penelitian yaitu kitab Fatawa al-Hindiyyah karya Syaikh Nizamuddin Al-Balkhi.

a. Data Sekunder

Data sekunder adalah data yang berasal dari sumber kedua atau dari instansi seperti dokumen. Sumber data juga menjadi bahan pertimbangan dalam penentuan alat penelitian. Dalam pengertian lain data sekunder memiliki pengertian "Data yang tersusun dalam bentuk dokumen dokumen".

Analisis data adalah proses mencari dan menyusun secara sistematis data yang diperoleh dari hasil wawancara, catatan lapangan, dan bahanbahan lain, sehingga dapat mudah dipahami, dan temuannya dapat diinformasikan kepada orang lain. Analisis data dilakukan dengan mengorganisasikan data, menjabarkannya ke dalam unit-unit, melakukan sintesa, menyusun ke dalam pola, memilih mana yang penting dan yang 
akan dipelajari, dan membuat kesimpulan yang dapat diceritakan kepada orang lain (Sugiyono, 2007:224).

Bogdan \& Biklen mengatakan teknik analisis data adalah upaya yang dilakukan dengan jalan bekerja dengan data, mengorganisasikan data, memilah-milahnya menjadi satuan yang dapat dikelola, mensintesiskannya, mencari dan menemukan pola, memutuskan apa yang dapat diceritakan kepada orang lain (Moleong, 2007:248).

\section{HASIL PENELITIAN DAN PEMBAHASAN}

\section{Biografi Syaikh Nizhamuddin Al-Balkhi}

Di benua India pernah terdapat kerajaan Islam yang besar yang didirikan oleh keturunan raja Mongol. Kerajaan ini berkuasa selama kurang lebih tiga abad. Dalam kurun waktu tersebut Islam telah memberi warna di tengah masyarakat yang mayoritas penduduknya beragama Hindu. Gaung kebesaran Islam masih terlihat hingga kini, seperi Taj Mahal, serta istana dan masjid-masjid megah dengan arsitektur yang bernilai tinggi dan menjadi acuan bagi kemajuan arsitektur modern. Di samping itu populasi muslim di anak benua India ini merupakan salah satu populasi muslim terbesar di dunia. Inilah kerajaan Mughal atau Mogul yang didirikan oleh Zahiruddin Babur pada tahun 1526 M, yang merupakan cucu dari Timur Lenk dari pihak ayah dan cucu Jengis Khan dari pihak ibu. Kerajaan ini beribukota di Delhi India.

Salah satu raja Mughal yang mengantarkan kerajaan Mughal kepada sebuah kejayaan adalah Abul Muzaffar Muhyiddin Muhammad Aurangzeb Alamgir. Ia memerintah Mughal selama 47 tahun sejak tahun 1659 hingga 1707.

Dalam catatan sejarawan, secara umum pemerintahan Muslim di India menampilkan kesimpulan yang berbeda-beda sesuai dengan perspektif mereka dalam menyajikan karakter sejarah. Sebagai pemimpin dianggap sebagai pemimpin besar, dan sebagian lain dianggap sebagai pemimpin tiran yang kejam. Kaisal Aurangzeb Alamgir adalah salah seorang pemimpin Mughal yang dianggap oleh sejarawan sebagai pemimpin yang kontroversial, kejam dan intoleran.

Menurut pandangan kalangan Hindu dan Sikh, Aurangzeb dipandang sebagai kaisar bengis, memberlakukan kebebasan terbatas, pemeras, dan memberlakukan rezim agama yang intoleran, sebagaimana diadopsi oleh para sejarawan pada umumnya. Namun, pada hakikatnya Kaisar Aurangzeb adalah orang yang religius, dan adil, lebih dari seorang raja (http. Etafaquh.co.id. di unduh tanggal 2 September 2018).

Memandang latar belakang kehidupan awal Aurangzeb adalah sangat penting ketika dalam masa pemerintahannya selama 49 tahun, kerajaan Mughal setelah 150 tahun bercokol di India menjadi sebuah kerajaan yang berada di puncak kejayaan, yang menguasai sebagian besar 
wilayah anak benua India, dan menjadi salah satu negara terkaya di dunia.

Aurangzeb lahir pada tahun 1618 dalam lingkungan istana dengan kekayaan yang berlimpah. Ayahnya adalah Kaisar Shah Jehan yang membangun Taj Mahal di Agra, sebuah bangunan makam yang sangat indah yang dipersembahkan untuk ibunya, Mumtaz Mahal. Namun, di tengah kemewaan istana dan bergelimangnya harta, Aurangzeb dididik ayahnya dengan pendidikan yang baik. Ia dikirim kepada para ulama untuk menimba ilmu agama, hingga dalam usia muda ia sudah menjadi seorang yang menguasai berbagai disiplin ilmu, al-Quran, hadits, fiqh dan ilmu-ilmu keislaman lainnya. Ia juga terlatih dalam seni kaligrafi. Beberapa hasil karya kaligrafinya masih ada hingga kini.

Ketika Aurangzeb diangkat menjadi penguasa Mughal menggantikan ayahnya, ia berkomitmen untuk membawa Mughal kepada pemerintahan Islam, setelah sebelumnya tidak begitu mewarnai dalam permerintahan. Saat pemerintahan dirinyalah sebuah kodifikasi hukum islam diterbitkan sebagai sarana rujukan penerapan hukum islam. Buku setebal 6 jilid ini disusun oleh Lajnah Ulama Mughal yang dipimpin oleh Nizamuddin Al-Balkhi. Al-Fatawa Al-Hindiyah, begitu buku kodifikasi hukum Islam berdasar madzhab Imam Hanafi ini dikenal. Buku ini ditulis/disusun pada awal abad $12 \mathrm{H} / 18 \mathrm{M}$. oleh kelompok Ulama besar India yang dipimpin oleh Syaikh Nizhamuddin Al-Balkhi atas permintaan Sultan Mughal India Abu Muzhaffar Muhyiddin Muhammad Aurangzeb.

Aurangzeb mengirimkan kitab fatawa ini ke seluruh penjuru kekuasaannya, untuk memberlakukan hukum Islam. Alcoholisme diberantas, perjudian dan prostitusi diperangi, pajak-pajak dihapuskan, dan acara-acara yang mengandung kemunkaran, baik yang dilakukan masyarakat maupun pemerintah dihapuskan.

Prestasi Aurangzeb dalam mengisi pemerintahan dan warna Islam memang tidak dapat dibantah lagi. Tetapi sebagian para ahli sejarah dan kalangan akademisi masih tetap bersuara lantang, bahwa warisan Aurangzeb bagi rakyat India adalah intoleransi dan penindasan. Ia sering disebut sebagai penggusur kuil, pembunuh non muslim dan sewenangwenang kepada rakyatnya.

Namun sebenarnya, sikap Aurangzeb tidaklah demikain. Ia tidak pernah bertindak sewenang-wenang, tidak pernah bersikap diskriminatif dan tidak pernah melakukan perbuatan yang bersifat Intoleransi. Hal ini dapat dibuktikan dengan struktur pemerintahannya yang majemuk. Puluhan pemeluk Hindu dan Sikh bekerja di Istana sebagai pejabat, penasihat dan anggota militer. Maka, dari sini jelas, bahwa Aurangzeb bukan seorang yang kaku dalam beragama yang serta merta menolak kontribusi non muslim.

Isu negatif lainnya yang ditudingkan kepada Aurangzeb adalah, masa pemerintahannya diwarnai dengan penghancuran kuil-kuil Hindu dan Shikh serta menolak adanya pembangunan rumah ibadah yang baru. 
Hal ini seolah-olah menjadi fakta sejarah yang tak terbantahkan.

Perlu diketahui, penjagaan dan pelestarian candi dan kuil oleh umat Islam -dengan standar legal dalam hukum Islam- telah berlangsung sekian lama. Pasukan Islam pertama kali datang ke India pada tahun $711 \mathrm{M}$. di bawah pimipinan Muhammad bin Qasim yang telah memberikan jaminan beragama dan keamanan pada kuil-kuil Hindu dan Budha. Aturan yang sama pun diberlakukan selama ratusan tahun sebelum kerajaan Mughal berkuasa. Aurangzeb tidak mengabaikan hukum-hukum Islam terhadap kelompok minoritas atau kelompok mayoritas yang tidak memiliki kekuasaan. Ia juga mengetahui bahwa syariat Islam melarang penodaanpenodaan terhadap tempat ibadah. Ia mengatakan, "Menurut keyakinan dan syariat Islam, kuil-kuil yang merupakan peninggalan zaman sebelumnya tidak selayaknya dihancurkan".

Jika Aurangzeb berkeyakinan bahwa penghancuran kuil-kuil atau tempat peribadatan adalah bertentangan dengan syariat Islam, lalu bagaimana isu bahwa ia melakukan pengrusakan bisa muncul? Jawabannya adalah hal tersebut merupakan kebohongan yang dibuat-buat oleh lingkungan politik kuil.

Perlu diketahui, kuil-kuil Hindu dan Shikh bukan hanya tempat untuk beribadah semata, akan tetapi kuil juga memiliki pengaruh politik yang siknifikan. Kuil berfungsi sebagai pusat perpolitikan dan bagian dari negara, kepala kuil juga bekerja kepada pemerintah. Saat raja-raja Mughal atau raja Hindu di luar daerah Mughal ingin mendekati rakyat, maka mereka terlebih dahulu mendekati tokoh-tokoh agama di kuil untuk mendapatkan simpatik dari rakyat di wilayah tersebut. Dengan demikian, kuil pada saat itu lebih dari sekedar bangunan yang bersifat religius, akan tetapi ia juga merupakan sebuah potensi untuk menggapai pengaruh politik.

Setelah mengetahui fungsi kuil yang signifikan, barulah kita membahas dan memahami mengapa Aurangzeb sampai menghancurkan kuil-kuil tertentu. Tidak ada catatan minor dalam sejarah yang mengisahkan bahwa Aurangzeb menghancurkan kuil di India secara serampangan. Kuilkuil yang ia hancurkan benar-benar telah diputuskan dengan kebijakan yang matang dan juga hanya sebagian kecil dari total kuil-kuil Hindu yang ada di India. Keputusan penghancuran kuil itu tidak dilandasi oleh sentiment keagamaan, akan tetapi lebih kepada faktor politik yang dapat membahayakan stabilitas kerajaan dan masyarakat Mughal.

Kepala-kepala suku dan tokoh-tokoh agama mengadakan pemberontakan di masa Aurangzeb juga dilatarbelakangi kekecewaan mereka terhadap kepemimpinan Shah Jahan -ayah Aurangzeb- yang mengutamakan kemewahan dan menyebabkan himpitan perekonomian. Ketika pemberontakan pecah di salah satu wilayah Mughal, maka kuil-kuil setempat merupakan corong utama yang memprovokasi masyarakat untuk mengadakan pemberontakan. Oleh karena itu, selama pemimpin pemberontakan ada dan kuil-kuil pendukung mereka tetap eksis, maka 
stabilitas keamanan di wilayah Mughal akan sulit diwujudkan.

Oleh karena itu ditegakkan aturan, perang terhadap para pemberontak berkonsekuensi menghancurkan tempat pemberontakan itu dirancang, yaitu kuil. Contohnya adalah pemberontakan yang terjadi pada tahun 1669 M, di Banaras yang dipimpin oleh rival politik Mughal, Shivaji. Ia menggunakan kuil setempat untuk mendukung aksinya. Setelah memberantas kelompok Shivaji, Aurangzeb menghancurkan kuil di Banaras yang digunakan sebagai tempat penyusunan strategi untuk memberontak kepada pemerintah. Peristiwa serupa juga terjadi pada tahun $1670 \mathrm{M}$ di Mathura, pemberontak di daerah tersebut membunuh tokoh-tokoh agama Islam. Metode pemberantasan yang sama diterapkan Aurangzeb, yakni menghancurkan kuil yang menyeponsori pemberontakan tersebut.

\section{Pendapat Al-Balkhi Ittishal Antara Ijab Dan Kabul Akad Nikah}

Menurut Syaikh Nizhamuddin Al-Balkhi dalam kitab fatawa alhindiyah (2002) mengatakan:

ومنها ان يكون الايجاب والقبول في بجلس واحد حتى لو اختلف البملس بان كان حاضرين فاوجب

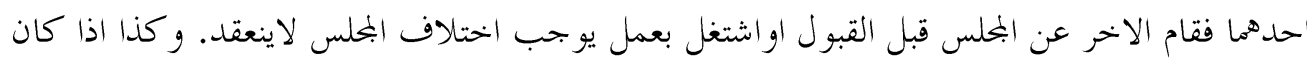

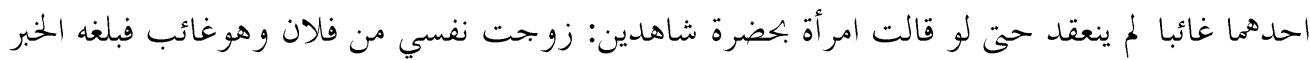

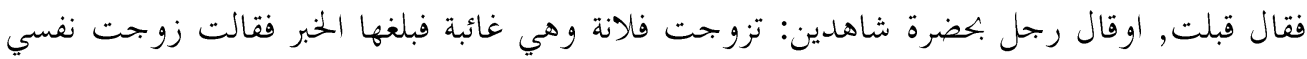

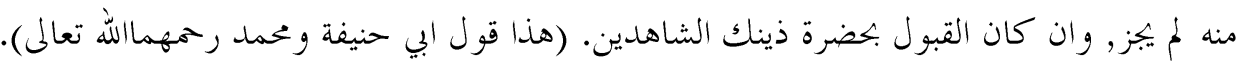

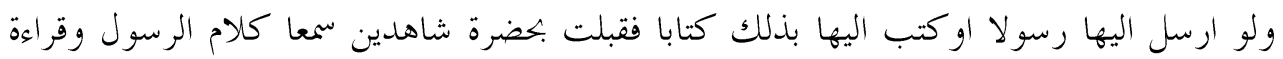

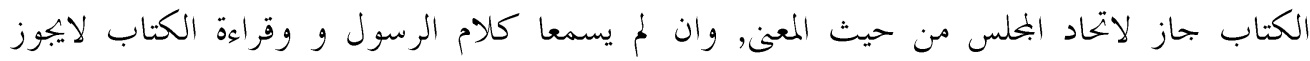

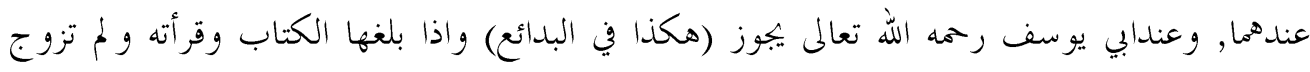

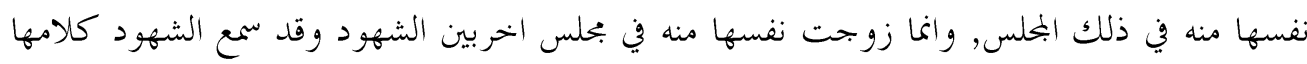
وما في الكتاب يجوز النكاح (كما في الخلاصة).

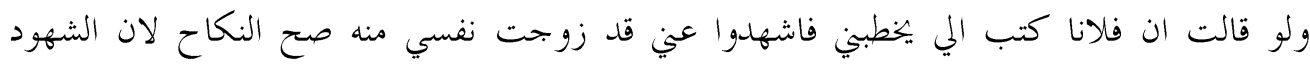

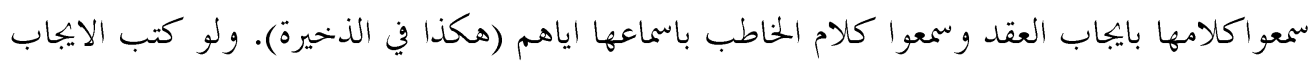

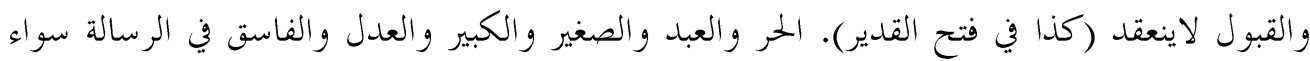

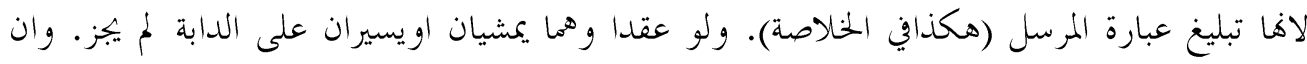

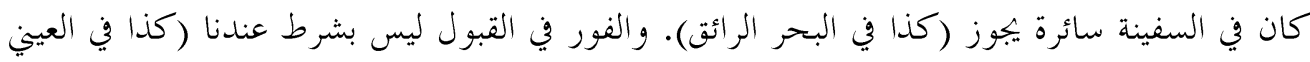
شرح الهداية).

“Dari sebagian syarat dan rukun akad nikah yaitu antara ijab dan kabul harus satu majlis, Sehingga apabila beda majlis seperti dua orang yang akad hadir, yang satu mengucapkan ijab, lalu calon mempelai laki-laki berdiri 
dari majlis akad tadi sebelum mengucapkan kabul, atau sibuk dengan pekerjaan lain yang membelokan dari majlis, maka akad tersebut dinyatakan tidak sah karena tidak dalam satu majlis. Begitu juga apabila salah satu diantara orang yang akad tidak hadir dalam majlis akad, maka akadnya tidak sah, seperti kalau mempelai wanita berkata dihadapan dua saksi: Aku kawinkan diriku kepada fulan (lelaki yang tidak disebut namanya) dan lelaki tersebut tidak hadir di majlis tersebut, tetapi khabar tersebut sampai ke fulan dan fulan berkata: Aku terima, atau seorang laki-laki berkata dihadapan dua saksi: aku nikahi fulanah (wanita yang tidak disebut namanya) dan fulanah tersebut tidak hadir di majlis akad, tetapi khabar tersebut sampai ke fulanah, seraya berkata: aku kawinkan diriku kepada lelaki tersebut, maka akad tersebut tidak sah walaupun pengucapan kabul dihadapan dua orang saksi tadi. Kalau seorang laki-laki mengirim utusan kepada seorang wanita atau mengirim surat lalu wanita itu menerima dengan hadir dua orang saksi yang mendengar ucapan utusan atau membaca surat tersebut maka hukumnya boleh karena masih dihitung satu majlis akad secara makna. Tetapi apabila dua saksi tersebut tidak mendengar ucapan utusan dan tidak membaca surat tersebut maka akadnya tidak sah. Apabila sampai surat kepada fulanah terus dibaca tetapi wanita tersebut tidak mengawinkan dirinya kepada lelaki tersebut di majlis itu, tetapi dia mengawinkanya di tempat yang lain dihadapan beberapa saksi dan saksi itupun mendengar ucapan waita itu maka sah nikahnya".

Apabila berkata seorang wanita: sesungguhnya fulan telah mengirim surat padaku, isinya ingin melamarku. Terus wanita tersebut minta untuk disaksikan kepada para saksi, dia berkata: aku telah kawinkan diriku kepadanya, maka sah nikahnya. Dikatakan sah nikahnya, karena semua saksi mendengar ucapan wanita tersebut untuk mengijab akad dan para saksi mendengar surat yang dibacakan dihadapan para saksi. Tetapi apabila ijab dan kabul keduanya berbentuk surat maka nikahnya tidak sah. Hukum itu berlaku bagi semua baik orang yang merdeka maupun 'abid, yang masih kecil maupun yang dewasa, yang 'adil maupun yang fasiq.

Apabila melakukan akad nikah dua orang yang sedang berjalan atau sedang naik kendaraan maka tidak sah akad nikahnya. Sedangkan apabila melakukan akadnya di dalam kapal laut yang sedang berjalan maka sah akad nikahnya.

Menurut Syaikh Nizhamuddin Al-Balkhi faur bukan merupakan syarat nikah. Catatan penting dari pendapat Syaikh Nizhamuddin Al-Balkhi diantaranya: (Al-Balkhi, 2002:343).

a. ijab kabul harus dilakukan satu majlis

b. Mempelai wanita boleh menikahkan dirinya sendiri

c. Lafadz shighat akad nikah bukan hanya lafadz inkah dan tazwij tapi boleh boleh dengan lapadz ghair sharih, tetapi lafadz yang semakna dengan inkah dan tazwi, seperti hibah, tamlik, dan lain-lain. 
Dasar dalil yang digunakan oleh Syaikh Nizhamuddin Al-Balkhi dalam melakukan istinbath hukum tentang ittishal antara ijab kabul dengan menggunakan langkah sebagai berikut:

a. Al-Qur'an

Al-Qur'an dalam kajian Ushul Fiqh merupakan objek pertama dan utama pada kegiatan penelitian dalam memecahkan suatu hukum. AlQur'an adalah kalam Allah yang diturunkan oleh-Nya melalui perantaraan malaikat Jibril ke dalam hati Rasulullah Muhammad bin Abdullah dengan lafadz yang berbahasa Arab dan makna-maknanya yang benar, menjadi undang-undang bagi manusia yang mengikuti petunjuknya (Khalaf, 1994:18). Dari segi bahasa, al-Qur'an merupakan bentuk mashdar dari kata qaraa, yang diambil dari wajan fu'lan, yang berarti bacaan (Shidik, 2001:17). seperti terungkap dalam surat al-Qiyamah. Allah berfirman: "Sesungguhnya atas tanggungan kamilah mengumpulkannya (di dadamu) dan (membuatmu pandai) membacanya. Apabila Kami telah selesai membacakannya, Maka ikutilah bacaannya itu (Q.S.Al-Qiyamah :17-18).

Adapun secara terminologi adalah Kalam Allah yang di turunkan kepada Nabi Muhammad SAW. dalam bahasa Arab yang di nukilkan kepada generasi sesudahnya secara mutawatir, tertulis dalam mushaf, membacanya merupakan ibadah, di mulai dari surat al-Fatihah dan di akhiri dengan surat an-Nas (Shidik, 2001:18).

Dalam al-Quran tidak ada yang membahas secara khusus tentang persoalan ittishal antara ijab kabul akan tetapi beberapa ayat al-Quran yang bisa dijadikan dalil, yaitu mengenai ijab kabul. Di antaranya firman Allah SWT.: "Maka tatkala Zaid telah mengakhiri keperluan terhadap istrinya (menceraikannya), Kami kawinkan kamu dengan dia supaya tidak ada keberatan bagi orang mukmin untuk (mengawini) isteri-isteri anak-anak angkat mereka, apabila anak-anak angkat itu telah menyelesaikan keperluannya daripada isterinya" (Q.S. Al-Ahzab:37).

b. Al-Hadits

Kata sunnah secara bahasa berarti perilaku seseorang tertentu, baik perilaku yang baik atau perilaku yang buruk. Dalam pengertian inilah dipahami kata sunnah dalam sebuah hadits Rasulullah SAW.:

$$
\begin{aligned}
& \text { عن المنذربن جرير عن ابيه عن النبي صلى الله عليه وسلم قال من سن في الاسلام سنة حسنة فعمل ها }
\end{aligned}
$$

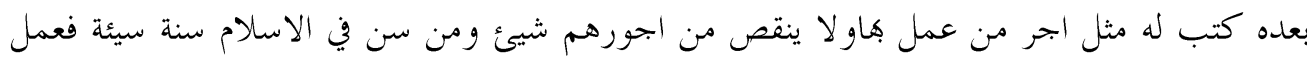

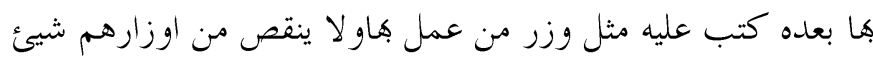

“Dari al-Munzir bin Jarir, dari bapaknya, dari Nabi Muhammad.bersabda: Barangsiapa yang melakukan perilaku (sunnah) yang baik dalam Islam ini, maka ia akan mendapat pahalanya dan pahala orang yang menirunya dan sedikit pun tidak dikurangi, dan barangsiapa yang melakukan perilaku (sunnah) yang buruk dalam Islam, maka ia akan mendapat dosanya dan 
dosa orang yang menirunya dan sedikit pun tidak dikurangi" (HR.Muslim, 2006:112).

As-Sunnah merupakan sumber hukum Islam kedua setelah alQur'an, sebagai penjelas dan memperinci ayat al-Qur'an yang mujmal (global). Berdasarkan firman Allah SWT: "Dan tidaklah kami turunkan alQuran kepadamu kecuali untuk kamu jelaskan kepada mereka tentang apa yang mereka perselisihkan itu dan menjadi petunjuk dan rahmat bagi kaum yang beriman" (Q.S. An-Nahl:64).

Bukan hanya itu pula, sunnah juga meliputi perkataan, perbuatan, taqrir (persetujuan), sifat dan sirah Nabi Muhammad. yang terekam dalam kehidupan dan perjuangan beliau. Meliputi kumpulan perkataan, kejelasan hukum, ilmu pengetahuan, rahasia agama, hakikat wujud, kemuliaan akhlak, keindahan hukum, pendidikan. Dengan demikian sunnah dilihat dari segi materi dan esensinya terbagi menjadi tiga macam: Sunnah Qauliyah (ucapan), Sunnah Fi'liyah (perbuatan), dan Sunnah Taqririyah (ketetapan). Adapun sebuah hadits yang bisa dijadikan dalil bahwa ijab kabul harus satu majlis, diantaranya:

$$
\begin{aligned}
& \text { ان ام حبية تحت عبيد الله بن جحش فمات بارض الحبشة فزوجها رحمه الله تعالى من النبي صلى الله }
\end{aligned}
$$

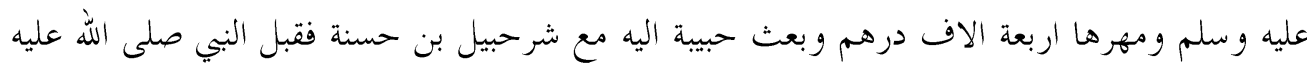

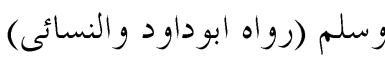

"Bahwasannya Ummu Habibah adalah istri 'Ubaidillah bin Jahsy. Ubaidillah meninggal di negeri Habasyah, maka raja Habasyah (semoga Allah memberi rahmat kepadanya) menikahkan Ummu Habibah kepada Nabi Muhammad. ia bayarkan maharnya 4000 dirham, lalu ia kirimkan Ummu Habibah kepada Nabi Muhammad. bersama Syurahbil bin Hasanah. Lalu Nabi Muhammad menerimanya" (HR. Daud dan Nasa'i).

Kemudian dalam hadits yang lain, Nabi Muhammad menikahkan dua orang dengan tanpa mempertemukan mereka dalam satu majelis. Sebagaimana dalam hadits berikut ini:

$$
\begin{aligned}
& \text { عن عقبة بن عامر ان النبي صلى الله عليه وسلم قال لرجل اترضى ان ازوجك فلانة النه؟ قال نعم, فقال }
\end{aligned}
$$

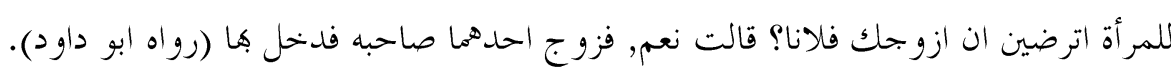

“Dari Uqbah bin Amir, bahwa Nabi Muhammad pernah berkata kepada seorang laki laki: Sukakah engkau aku kawinkan dengan si Fulanah? Ia menjawab: ya, dan Nabi bertanya kepada si wanitanya: Sukakah engkau aku kawinkan dengan si Fulan? wanita itu menjawab: ya, lalu dikawinkan antara mereka, lalu mereka menjadi suami isteri" (HR. Abu Dawud).

Berdasarkan dua hadits di atas memberikan keterangan bahwa menikahkan seorang wanita kepada seorang laki-laki tanpa keduanya bertemu itu boleh dilakukan. Berarti sesuai dengan urutan prioritas dari proses ijtihad Syaikh Nizhamuddin Al-Balkhi yang mengikuti jejak mazhab Imam Hanafi, yaitu ketika tidak ada dalam al-Qur'an maka akan mencari dalam hadits. sedang dalam hadits ditemukan bahwa ada praktek 
perkawinan dimana antara mempelai laki-laki yang mengucapkan kabul tidak berada dalam satu tempat dengan orang yang melakukan ijab, sebagaimana yang ada dalam hadits di atas.

\section{KESIMPULAN}

Dari uraian yang telah dipaparkan di atas tentang keharusan ittihad al-majlis dalam ijak kabu akad nikah menurut pendapat Syaikh Nizhamuddin al-Balkhi, maka dapat disimpulkan sebagai berikut: (1) Pendapat Syaikh Nizhamuddin Al-Balkhi dalam kitab Fatawa Al-Hindiyyah tentang ittishal antara ijab dan kabul dalam akad nikah yaitu ijab dan kabul harus satu majlis. Apabila beda majlis dalam mengucapkan ijab dan kabul maka akadnya tidak sah. (2) Dasar hukum yang digunakan oleh Syaikh Nizhamuddin Al-Balkhi dalam masalah ittishal antara ijab dan kabul akad nikah, yaitu hadits Nabi yang diriwayatkan oleh Abu Dawud yang artinya bahwasannya Ummu Habibah adalah istri 'Ubaidillah bin Jahsy. Ubaidillah meninggal di negeri Habasyah, maka raja Habasyah (semoga Allah memberi rahmat kepadanya) menikahkan Ummu Habibah kepada Nabi Muhammad. ia bayarkan maharnya 4000 dirham, lalu ia kirimkan Ummu Habibah kepada Nabi Muhammad. bersama Syurahbil bin Hasanah. Lalu Nabi Muhammad. menerimanya. Dalam hadits ini difahami oleh Syaikh Nizhamuddin al-Balkhi bahwa ijab kabul tidak mesti dalam satu tempat tapi dalam satu majlis akad.

\section{DAFTAR PUSTAKA}

Abdurrahman,(2014). Undang -Undang Nomor 1 tahun 1974 dan Kompilasi Hukum Islam di Indonesia. Jakarta: Grahamedia Press.

Abdurrahman, (1992). Kompilasi Hukum Islam di Indonesia. Jakarta: Akademik Presindo.

Al-Balkhi, Syaikh Nizhamuddin. (2006). Kitab Fatawa Al-Hindiyyah. Beirut : Dar al-Kutub al-Alamiyah.

Al-Bukhari. (2005). Kitab Shahih Bukhari. Beirut: Dar al-Kutub al-Alamiyah.

Al-Jaziri, Abdurrahaman. (1990). Kitab al-Fiqh 'Ala Mazahib al-Arba'ah. Juz.

IV. Beirut : Dar al-Kutub al-Alamiyah.

Al-Qardlawy, Yusuf. (1987). Ijtihad Dalam Syariah; beberapa pandangan analitis tentang Ijtihad Kontemporer. Jakarta: Bulan Bintang.

Ash-Shiddieqy, Muhammad Hasbi. (1971). Sejarah Pertumbuhan dan Perkembangan Hukum Islam. Jakarta: Bulan Bintang

Az-Zuhaili, Wahbah. (2011). Al-Figh Al-Islam Wa Adillatuhu. Jakarta: Gema Insan. 
Badran, Abdul Qadir. (t.t). Terjemah Syaikh Muwafaq Muallif alMuhgni dalam al-Muhgni. Beirut: Daar al-Kutub al-Ilmiyah.

Departemen Agama, RI.(2004). Al-Qur'an dan Terjemahannya. Bandung : sygma

Depdikbud, (1996). Kamus Besar Bahasa Indonesia. Jakarta: Balai Pustaka.

Dahlan, Abd. Rahman. (2011). Ushul Figh. Jakarta: Amzah.

Hasbiyallah. (2013). Figh dan Ushul Figh; Metode Istinbath dan Istidlal. Bandung: Rosdakarya.

Jad, Syaikh Ahmad. (2008). Fikih Sunnah Wanita; Panduan Lengkap Menjadi Muslimah Shalehah. Jakarta: Pustaka Al-Kautsar.

Khallaf, Abdul Wahab. (1994). Ilmu Ushul Figh. Semarang: Dina Utama.

Sayyed Hawwas, Abdul Aziz Muhammad Azzam \& Abdul Wahhab. (2011). Fiqh Munakahat: Khitbah, Nikah, dan Talak. Jakarta: Amzah.

Syafe'i, Rachmat. (2006). Fiqh Muamalah. Bandung: Pustaka Setia.

Syarifuddin, Amir. (2009). Hukum Perkawinan Islam di Indonesia; Antara Figh Munakahat dan Undang-Undang Perkawinan. Jakarta: Kencana.

Syureich, (1992). Membangun rumah tangga Bahagia. Jakarta: Sistimatis.

Syatha, Syaikh Muhammad. (2004). Kitab I'anatuth Thalibin. Semarang: AlHaramain

Shidik, Safiudin. (tt). Ushul Fiqh. Jakarta: Intimedia Ciptanusantara.

Tihami \& Sahrani,(2014). fikih munakahat. Bandung: Rajawali press.

Zahrah, Muhammad Abu. (1958). Usul al-Fiqh. Cairo: Daar al-Fikr al-'Arabi.

Zakariya, Abi Yahya. (1999). Kitab Fathul Wahab. Semarang: Al-Haramain.

Zuhaili,Wahbah. (2010). Figh imam syafii, Jakarta: Niaga swadaya. 